\title{
Öğretmen adaylarının öğretmenlik mesleğine yönelik tutumlarının bir yordayıcısı olarak bireysel değerler ${ }^{[*]}$
}

\author{
Hanifi PARLAR ${ }^{[* *]}$ \\ Ramazan CANSOY ${ }^{[* * *]}$
}

\begin{abstract}
Öz
$\mathrm{Bu}$ araştırmanın amacı öğretmen adaylarının bireysel değerleri ile öğretmenlik mesleğine yönelik tutumları arasındaki ilişkilerin incelenmesidir. Araştırmanın çalışma grubunu 20152016 eğitim-öğretim yllında İstanbul Ticaret Üniversitesi ve Karabük Üniversitesinde pedagojik formasyon programında öğrenim gören 210 öğretmen adayı oluşturmuştur. Araştırma verileri Kişisel Değerler Envanteri ve Öğretmenlik Mesleği Tutum Ölçeği kullanılarak elde edilmiştir. Verilerin analizinde aritmetik ortalama, Pearson Çarpım Momentler Korelâsyon Analizi ve Çoklu Doğrusal Regresyon Katsayısı kullanılmıştır. Araştırmada elde edilen bulgulara göre, öğretmen adaylarının bireysel değerlerinde dair algılarının ve öğretmenlik mesleğine yönelik tutumlarının yüksek düzeyde olumlu olduğu bulunmuştur. Bireysel değerler ile öğretmenlik mesleğine yönelik tutum arasında pozitif yönde anlamlı ilişkiler olduğu ortaya konulmuştur. Öğretmen adaylarının bireysel değerlerinin öğretmenlik mesleğine yönelik tutumu pozitif yönde ve anlamlı olarak yordadığı görülmüştür. Sonuçlar ilgili literatür bağlamında tartışılmıştır.
\end{abstract}

Anahtar kelimeler: Öğretmenlik mesleğine yönelik tutum, Bireysel değerler ve öğretmenlik, Aday öğretmen

\section{Personal values as a predictor of prospective teachers' attitude towards teaching profession}

\footnotetext{
Abstract

The purpose of this study was to examine the relationship between prospective teachers' personal values and attitude towards teaching profession. Participants of the study included a total of 210

[*] Bu çalışma, 21/24.04.2016 tarihinde Antalya’da yapılan 25. Ulusal Eğitim Bilimleri Kongresi’nde sözlü bildiri

[*] Yrd. Doç. Dr., İstanbul Ticaret Üniversitesi, Fen Edebiyat Fakültesi Eğitim Bilimleri Bölümü, Beyoğlu/ İstanbul, hparlar@ticaret.edu.tr.

${ }^{[* *]}$ Yrd. Doç. Dr., Karabük Üniversitesi, Edebiyat Fakültesi, Eğitim Bilimleri Bölümü, Karabük, ramazancansoy@karabuk.edu.tr.
} olarak sunulmuștur. 
teacher candidates from The Karabük University and The İstanbul Commerce University in the 2015-2016 academic year. "A Personal Values inventory" and "Attitude Scale towards the Teaching Profession" were the data collection instruments. Arithmetic mean, Pearson Product-Moment Correlation Coefficient and Multiple Linear Regression Analysis were used to analyze the data. The results of the study showed that the level of teacher candidates' values and attitudes towards the teaching profession were positive and high. The dimensions of Personal Values Inventory and the Attitude Scale towards the Teaching Profession correlated positively. The personal values of the prospective teachers were found to predict their attitudes towards teaching profession. Results of the study were discussed in line with the related literature and some implications were presented.

Keywords: Teacher attitudes towards the profession, personal values, prospective teacher

\section{Giriş}

Öğretmenlik mesleği değer odaklı bir meslektir. Bu mesleği yapmak isteyenlerin bireysel değerlerini ortaya koyabilecek davranış örüntülerine ve tutumlarına sahip olması beklenir. Bireylerin değerleri yaşam felsefelerini oluşturmakta ve zamanla hayatlarına yön verebilmektedir. Değerler bireylerin hayatında ve toplumda etkili olmakta ve yön vermektedir (Ekşi, 2003). Toplumsal yapı içinde ise eğitim kurumları değerlerin kazanıldığı en önemli alanların başında gelmektedir. Dolayısıyla öğretmenler toplumsal yapının içindeki değerlerin odağında bulunmaktadır. Yani öğretmenler önemli birer değer aktarıcısı durumundadırlar. Bu noktada bireysel değerlerin önemi ortaya çıkmaktadır. Öğretmenlerin öğretime olan inançları bireysel değerlerden etkilenebilmektedir (Chong ve Low, 2009). Aynı zamanda öğretmenlerin eğitimle ilgili ahlaki değerleri bireysel değerler üzerinde inşaa edilmektedir (Fisher, 2013). Öğretmenler, öğrencilerinin ve kendi meslektaşlarının değer oluşumunda önemli rol modellerdir (Collinson, 2012). Bu bakımdan öğretmenlerin yetiştirilmesinde mesleğe uygun, değer katabilecek, yüksek idealleri olan, olumlu tutum geliştirmiş öğretmen adaylarına ihtiyaç duyulmaktadır (Tekneci, 2010). Öğretmenlerin meslek seçiminde ise tutumları etkili olabilmektedir. Öğretmenlik mesleğine yönelik tutum bireylerin içsel ve dışsal bazı özelliklerinden etkilenebilmektedir (Üstüner, Cömert ve Demirtaş, 2009). Bu bakımdan bu çalışmada öğretmen adaylarının bireysel değerleri ile öğretmenlik mesleğine yönelik tutumları arasındaki ilişkilerin araştırılması hedeflenmektedir.

Bireysel değerler, okul yönetimi, akademik iyimserlik, örgütsel değerlere uyum gibi farklı değişkenlerle ilişkilidir (Sezgin, 2006; Uzun, 2014; Yılmaz, 2006). Öğretmenlerin sahip olduğu değerler ile ilişkili olduğu düşünülen kavramlardan birisi de mesleğe yönelik tutumdur. Tutumlar öğrenme sonucu ortaya çıktığı gibi yaşantı ve kültürleme yoluyla öğrenilmekte, belirli dönemlerde süreklilik göstermekte, olumlu ya da olumsuz davranışların kaynağı olabilmektedir (Tavşancıl, 2014). Bu bağlamda öğretmen adaylarının görev aldıkları zaman görevlerini tam olarak yapmaya çalışmaları, öğrencilere karşı davranışlarında olumlu olmaları, alanlarında 
araştırmaya önem vermeleri, iletişim becerilerinin nitelikli olması öğretmenlik mesleğine yönelik olumlu tutumlarıyla yakından ilişkilidir (Çeliköz ve Çetin, 2004). Aynı zamanda öğretmenlerin mesleklerini sevmeleri ve aidiyet duygusu taşımaları, mesleğin sosyal olarak ciddi bir öneme sahip olduğunu hissetmeleri ve önemini kavramaları, kendilerini sürekli geliştirmeleri bu mesleğe yönelik tutumlarıyla ilişkilidir (Temizkan, 2008). Öğretmen adaylarının mesleğe yönelik tutumlarının olumlu yönde olmasının, öğretmenlerin okul içerisinde farklı alanlardaki başarılarını etkileyeceği düşünülebilir.

İlgili alan yazında öğretmenlik mesleğine yönelik tutum (Can, 2013; İlğan, Sevinç ve Arı, 2013; Kaşkaya, Ünlü, Akar ve Sağırlı, 2011; Kılcan, Keçe, Çepni, Kılınç, 2014; Özder, Konedralı ve Zeki, 2010; Sağlam, 2008) ve bireysel değerler ile ilgili (Aktepe ve Yel, 2009; Altunay ve Yalçınkaya, 2011; Çavdar, 2009; Demir, 2015) farklı çalışmalar bulunmaktadır. Bireysel değerler ile okul yönetimi (Yılmaz, 2006), akademik iyimserlik (Uzun, 2014), örgüt değerlerinin uyumu (Sezgin, 2006), rol fazlası davranışlar (Demir, 2015), stres ile olan (Bachkirova, 2005) ilişkilere bakılmıştır. Ancak öğretmen adaylarının bireysel değerleri ile öğretmenlik mesleğine yönelik tutumun incelendiği çalışmaların sınırlı düzeyde olduğu (Bektaş ve Nalçacı, 2012) ve yeni çalışmalara ihtiyaç olduğu görülmektedir. $\mathrm{Bu}$ durum alan yazındaki boşluğu göstermek suretiyle mevcut araştırmanın gerçekleştirilmesini gerekçelendiren en temel husustur. Öğretmen adaylarının bireysel değerleri ile mesleğe yönelik tutumları arasındaki ilişkinin ortaya konulması, gelecekteki sınıf içi-dışı tutum ve davranışları tahmin etmede kullanılabilir. Mesleki tutum ile bireysel değerler arasındaki uyumun ortaya konulması ile mesleğe uygun bireylerin seçimine yönelik çalışmalar yapılabilir. Bireysel değerlerin mesleğe yönelik tutumda önemli olduğunun görülmesi ile öğretmenlerde bireysel değerlere yönelik çalışmalar planlanabilir. Bu nedenle bu çalışmada öğretmen adayların mesleğe yönelik tutumlarının farklı bireysel değerler ile ilişkili olduğunu sorgulamanın önemli olduğu düşünülmektedir. Öğretmen adaylarının bireysel değerleri ile öğretmenlik mesleğine yönelik tutum arasında ilişkilerin ortaya konulmasıyla öğretmen yetiştirme programlarında bireysel değerleri geliştirmeye yönelik uygun politikalar belirlenebilir (Collinson, 2012). Bu nedenle araştırma sonuçlarına göre politika yapıcılar ve uygulayıcıların öğretmen yetiştirme programlarında yeniden planlamalar yapabilecekleri ve tedbirler alabilecekleri söylenebilir. Aynı zamanda bu çalışmanın bireysel değerler ile öğretmenlik mesleğine yönelik tutum arasındaki ilişkinin incelenmesinin ulusal alanyazına katkı sağlayabileceği düşünülmektedir.

\section{Bireysel değerler, öğretmenlik mesleğine yönelik tutum ve aralarındaki ilişkiler}

Değerler, insan davranışlarında önemli bir etken ve açıklayıcı (Güngör, 1993), bireylerin tercihlerinde etkin rol oynayan ve yön veren (Rokeach, 1973; Feather, 1975), toplumsal yaşamda önemli normları ve ilkeleri oluşturmakta (Kılıç, 2011), yaşamda iz bırakan ve kişisel güdülenmede (Kilby, 1993'den akt., Özensel, 2003) önemli bir kavramlardır. Değerler antroploglar tarafından kültürel yapının ana maddesi, felsefeciler tarafından ideal olanların ortaya konulması, sosyolojide toplumsal normları ve ilkeler, psikolojide ise davranışlara yön vermede güdüleyici olarak ele alınmaktadırlar. Kluckhohn (1951) tarafından yapılan tanımlamada "Değer, eldeki eylem şekilleri, araçları ve amaçları arasından yapılan seçimi etkileyen arzu edilen durumun açık veya örtülü, 
bir bireye veya grubun özelliğine özgü bir kavramdır”. Dolayısıyla değerlerin bireylerin hayatına yön verdiği ve rehberlik ettiği, iyi ve kötüyü ayırmada önemli referanslar olduğu söylenebilir. Bu bağlamda öğretmenlerin bireysel değerlerinin bilinmesi ve mesleğe ne kadar uyumlu ve uygun olduklarının anlaşılması, mesleğe yönlendirme açısından faydalı olur ( Aktay ve Ekşi, 2009). Çünkü iyi bir öğretmen sadece kuralları harfi harfine uygulayan değil, aynı zamanda karakter ve değer sahibidir (Carr, 2006).

Bireysel değerler toplumsal yapı içerisinde ve kültürle gelişme göstermektedir (Meglino ve Ravlin, 1998). Bireysel değerler çocukluktan itibaren gelişerek zihinsel ve bilişsel yapıların içinde yerin almaktadır (Murphy vd., 1997 ve Russell, 2000'den akt., Uyguç, 2003). Bireysel değerler vasitasıyla sosyal normlar oluşmakta, yararlı ve iyi olanlar ayırtedilmekte ve sosyal rollerin uyumlu bir şekilde yürütülmesi sağlanmaktadır (Fitcher, 1990). Değerlerin ölçülebilmesi üzerinde tartışmalar devam etmekle birlikte, bazı gözlenebilen davranışlar üzerinde odaklanmanın değerlerin yorumlanmasını kolaylaştıracağı belirtilmektedir (Aktay ve Ekşi, 2009). Bu bağlamda değerler üzerinde farklı çalı̧̧malar ve sınıflandırmalar bulunmaktadır.

Değerler üzerinde teorik olarak farklı sınıflandırmalar yapılmış̧ır. Bunlardan Spranger değeri altı grupta, Rokeach iki grupta, Schwartz ise on grupta toplamıştır. Spranger'in (1928) yaptığı sinıflandırmada temel değerler ve grupları şunlardır; (i) Teorik (Bilimsel) değer (ii) Ekonomik değer, (iii) Estetik değer, (iv) Sosyal Değerler, (v) Politik Değer, (vi) Dini Değerler oluşturmaktadır. Rokeach’a (1973) göre ise değerler temel değerler ve araç değerler olarak sınıflandırılmıştır. Temel değerler başarı, özgürlük, eşitlik gibi arzu edilen en son değerleri içermektedir. Araç değerler ise cesaret, tutku, sorumluluk gibi temel değerlere ulaşmak için vasita durumunda olan tavır ve davranışları içermektedir. Schwartz (2012) ise bireysel değer gruplarını şöyle sıralamaktadır Güç, başarı, hazcılık, uyarılım, özyönelim, evrenselcilik, iyilikseverlik, geleneksellik, uyma ve güvenliktir. Güç denetim ve kontrol gücünü, başarı kişisel başarı isteği, hazcılık kişisel ödüllendirme, uyarılım heyecan ve yenilik peşinde olma, özyönelim bağımsız düşünce, evrenselcilik hoşgörülü olma ve insani özellikleri koruma, iyilikseverlik ilişki içinde olunan insanları koruma ve geliştirme, geleneksel farklı kaynaklardan gelen fikirlere saygı duyma, uyma normlara uyma, her türlü güvenliğin sağlanması şeklindedir. Bireysel değerlere farklı bakış açlları olmakla birlikte, değerlerin ortak bir takım insani özelliklerde birleştiği düşünülebilir.

Profesyonel bir meslek olarak görülen öğretmenlik mesleğini yapanlarda temel bazı değerlerin olması beklenir. Bu bakımdan mevcut çalışma bağlamında ele alınan bireysel değerler dürüstlük ve paylaşım, güven ve bağışlama, disiplin ve sorumluluk, saygı ve doğruluk, paylaşım ve saygıdır (Roy, 2003). Dürüstlük ve paylaşım, yüksek ahlaki ve evrensel değerlere dayanır. Güven ve bağışlama sağlam bir güvenilirlik ve nitelikli ilişkiler ile uzlaşmaya dayanır. Disiplin ve sorumluluk kişinin kendine hâkim olmasını ve kontrol etmesini gerektirir. Saygı ve doğruluk, başkaları ile belirli değerler çerçevesinde ilişki kurma, haklara saygılı olma ve bunu bir yaşam biçimi haline getirmektir. Paylaşım ve saygı ise tam sorumluluk ve sadakat ile sağlıklı ilişkilerin bireyler ve örgütler arasinda kurulmasıdır. 
Tutumu farklılaştıran nedenler arasında bir tutumla ilgili olarak kişiye özgü duygu, düşünce ve davranışın gücü önemlidir. Bunun yanında kişinin bulunduğu ekonomik, sosyal, siyasal ve psikolojik etkilerin sonucunda ortaya çıkmaktadır (Usal ve Aslan, 2006). Tutumlar bilişsel, duyuşsal ve davranışsal öğelerden oluşmaktadır. Bilişsel öğeler inançlara, duyuşsal öğeler inanca dayalı duygulardan, davranışsal özellikler ise bazı tepkilere hazır bulunuşluktan oluşmaktadır (Çetin, 2006). Tutum kişilerin sahip olduğu eğilimler, kişisel bazı özellikler ve bireyler için anlamlı olan durumlarda görülmektedir (Usal ve Aslan, 2006). Mesleğe yönelik tutum bu noktada önemli görülmektedir. Çünkü öğretmenlerin mesleğine yönelik tutumları, davranışlarını ve sınıf içinde oluşturdukları öğrenme iklimini olumlu etkilemekte, öğrenci ve öğretmen ilişkilerinde olumlu yönde önemli bir etkiye yol açmaktadır (Küçükahmet, 1986 ve Morgan, 1984'den akt. Semerci ve Semerci, 2004). Öğretmen adaylarının bilgi, beceri, davranış ve tutumlarının, öğretmenliğe dair nitelik gelişiminde etkili olduğuna dair çalışmalar artmaktadır. Bu bağlamda bireyin kendi özelliklerine uygun seçeceği meslek ve mesleğe karşı tutum, bireysel ve toplumsal düzeyde önemlidir (Bozdoğan, Aydın ve Yıldırım, 2007). Öğretmen adaylarının mesleğe başladığında olumlu tutumlar geliştirmeleri, programlardaki başarıların ortaya koyulması ve olumsuz yönde bir tutum var ise yapılacak çalışmalar ile bu tutumların olumluya dönüştürülmesi bir gerekliliktir (Semerci ve Semerci, 2004). Bu bakımdan öğretmen adaylarının tutumlarını ve bu tutumları etkileyen değişkenlerin stratejik bir öneme sahip olduğu düşünülebilir.

Bireysel değerlerin incelenmesi, var olan tutumlar ile davranışların ortaya konulması ve tahmin edilmesi bakımından önemli bir gösterge olabilir (Aktay ve Ekşi, 2009). Bireysel değerler bireylerin davranışlarında önceliklerinin ne olduğuna dair farklı motivasyonlar oluşturmaktadır (Cartwright, 2007). Bireyler kendi değerlerinin farkında oldukları karar vermede stratejilerini daha rahat belirleyebilmektedirler (Gibb, 2010). Tutum, bireysel değerler ile davranış arasındaki önemli bir aracı rol üstlenmektedir (Ajzen ve Fishbein, 2005'den akt. Bhattacharyya, 2014). Bireysel değerlerin, tutumları ve davranışları etkilediğine dair kanıtlar bulunmaktadır (Homer ve Kahle 1988; Papagiannakis and Lioukas, 2012). Bu ifadelerden hareketle değerler ile tutumların bir biri ile iç içe geçtiği ve aralarında ilişkkiler olduğu söylenebilir.

Öğretmenlik mesleğini yapacak adaylarının kişisel düzeyde bir takım özellikleri taşımaları günümüzün değişen toplum yapısında daha çok önem kazanmıştır. Türkiye’de öğretmen seçme ve yerleştirme sürecinde sınav odaklı bir yapı olması, bu meslek için uygun bireylerin seçilmesini zorlaştırmaktadır. Ancak diğer taraftan mevcut durumda daha nitelikli öğretmenler yetiştirmek ve öğretmenlere yönelik kapasite oluşturmak gerekmektedir. Dolayısıyla bireysel değerler ile ilişkisi olduğu düşünülen, mesleğe yönelik tutumun araştırılarak sonuçlarının ortaya konulması önemli görülmektedir. Değer ve tutum kavramlarının yapısından dolayı araştırmada bazı sinırllıklar bulunmaktadır. Bu araştırmadaki sınırlılıklardan en önemlisi, değerler konusundaki tartı̧̧aların, sınıflamaların ve değer araştırmalarında izlenecek yol ve yönteme ne derece güvenilebileceğine dair tartışmaların devam etmesidir. Ancak gözlenebilen ve ölçülebilen özellikler bağlamında kavramlar üzerinde daha kolay yorumlar yapılabilecektir (Aktay ve Ekşi, 2009). Bu araştırmada değer ve tutum iki farklı kavram olarak ele alınmış, değerlerin tutumları yordadığ düşünülmüş ve araştırma bu sinırlllıklar çerçevesinde yürütülmeye çalışılmıştır. $\mathrm{Bu}$ 
bağlamda öğretmen adaylarının bireysel değerleri ile öğretmenlik mesleğine yönelik tutumların ortaya konulması, bireysel değerleri geliştirmeye ve eğer öğretmenlik mesleğine yönelik olumsuz tutum var ise, bunu olumluya çevirmeye yönelik çıkarımlarda bulunmayı sağlayabilir. Bu amaçla bu araştırmada aşağıdaki sorulara yanıt aranacaktır:

1. Öğretmen adaylarının bireysel değerleri ve öğretmenlik mesleğine yönelik tutumları ne düzeydedir?

2. Öğretmen adaylarının bireysel değerleri ile öğretmenlik mesleğine yönelik tutum düzeyleri arasında anlamlı ilişkiler var mıdır?

3. Öğretmen adaylarının bireysel değerleri öğretmenlik mesleğine yönelik tutumu yordamakta midir?

\section{Yöntem}

\section{Desen}

$\mathrm{Bu}$ araştırma kişisel değerlerin; disiplin ve sorumluluk, güven ve bağışlama, dürüstlük ve paylaşım, saygı ve doğruluk, paylaşım ve saygı boyutlarının, öğretmenlik mesleğine yönelik tutumu yordama düzeyini incelemek için ilişkisel modelde hazırlanmıştır. Bu çalışmada kişisel değerler bağımsız değişken, öğretmenlik mesleğine yönelik tutum ise bağımlı değişkendir.

\section{Çalışma grubu}

Araştırmanın çalışma grubunu, araştırmacıların ulaşabildiği ve izin alabildiği, gönüllük esasına göre uygulamaya katılan, 2015-2016 eğitim-öğretim yılında İstanbul Ticaret Üniversitesi ve Karabük Üniversitesinde pedagojik formasyon programinda öğrenim gören toplam 210 öğretmen adayı oluşturmaktadır. Çalışmada sözel ders öğretmen adayı 142(\%67), Sayısal öğretmen adayı 37(\%17), uygulamalı dersler öğretmen adayı 31(\%14) kişidir. Katılımcıların \%75’ i kadın, \%25’i erkek öğretmen adayıdır. Adayların yaşları 22-25 aralığında değişmektedir. Katılımcıların geldikleri bölümler İngiliz Dili ve Edebiyatı 31(\%31.4), Coğrafya 23(\%10), Sanat Tarihi 8(\%3.5), Arkeoloji 2(\%0.9), Türk Dili ve Edebiyatı 16(\%6.9), Fizyoterapi ve Rehabilitasyon 1(\%0.4), Hemşirelik 7(\%3), İlahiyat 25(\%10.8), Müzik, Resim 2(\%0.9), Tarih 14(\%6.1), Matematik 22(\%9.5), Kimya 4(\%1.7), Fizik 1(0.4), Spor Yöneticiliği 4 (\%1.7), diğer 71(\%30.7) şeklindedir. Bu çalışma 2015-2016 yılında araştırmanın yapıldığı durum ve zamanla sınırlıdır.

\section{Veri toplama araçları}

Araştırma kapsamında kullanılan veri toplama aracı iki bölümden oluşmaktadır. Birinci bölümde araştırmaya katılan öğretmen adaylarının cinsiyet, yaş, mezun oldukları lise ve öğretmenlik yapmak istedikleri branş bilgileri bulunmaktadır. İkinci bölümde ise öğretmen adaylarının kişisel değerlerinin düzeyini görmek amacıyla Kişisel Değerler Envanteri ile Öğretmenlik Mesleği Tutum Ölçeği kullanılmıştır. 
Kişisel Değerler Envanteri: Roy (2003) tarafından geliştirilen bu envanter Asan, Ekşi, Doğan ve Ekşi, (2008) tarafından Türkçeye uyarlanmıştır. 47 maddeden oluşan envanterde, "(1)Beni hiç tanımlamaz','(5)Beni her zaman tanımlar” arasında ifade edilen, 5'li dereceleme ölçeği kullanılmıştır. Ölçek için Asan, Ekşi, Doğan ve Ekşi (2008) tarafından yapılan faktör analizi sonucunda beş boyutlu bir yapı ortaya çıkmıştır. Oluşan beş faktörün açıklanan toplam varyans miktarı \%41,24'tür. Disiplin ve sorumluluk boyutu 16 maddeden, güven ve bağışlama boyutu 12 maddeden, dürüstlük ve paylaşım boyutu 9 maddeden, saygı ve doğruluk boyutu 6 maddeden, paylaşım ve saygı boyutu 4 maddeden ve ölçek beş alt boyuttan oluşmaktadır. Her bir alt boyutun güvenirlik değerinin hesaplanmasında kullanılan Cronbach’s Alpha katsayısının değeri .60 ile .71 arasında değişmektedir. Mevcut araştırmada ise Cronbach's Alpha değerleri sırasıyla disiplin ve sorumluluk için .85 , güven ve bağışlama için .72, dürüstlük ve paylaşım için .66, paylaşım ve saygı boyutları için .71 ve saygı ve doğruluk boyutu için ise .30 olarak bulunmuştur. Disiplin ve sorumluluk örnek maddeleri "Adanmış bir çalışanım”, “Güvenilir biriyim”, Güven ve bağışlama örnek maddeleri "Hata yapan insanları affedebilirim." ve "Özür dilerim" demek benim için kolaydır”, Dürüstlük ve paylaşım örnek maddeleri "Sözüm senedimdir., "Paylaşmacı biriyimdir.," Saygı ve doğruluk örnek maddeleri "Kendi hatalarım hakkında dürüst olabilirim., "Bence özür dilemek zayıflık işaretidir.", Paylaşım ve saygı örnek maddeleri "Diğer insanların katkısına saygı duyarım.," "Bence paylaşmak iyi ve sağlıklı bir ilişkinin temelidir." şeklindedir.

Öğretmenlik Mesleği Tutum Ölçeği: Çetin (2006) tarafından geçerlilik ve güvenirlik çalışması yapılarak geliştirilen ölçek 35 maddeden oluşmaktadır. Likert tipinde hazırlanan Ölçek "(1) Asla katılmam”, “ (5) Kuvvetle katılırım” arasında ifade edilen 5'li dereceleme ölçeği kullanılmıştır. Ölçekte açıklanan toplam varyans \%51 olarak bulunmuştur. Ölçek sevgi boyutu 22 maddeden, değer boyutu 8 maddeden ve uyum boyutu 5 maddeden oluşmaktarr. Ölçek üç alt boyuttan oluşmaktadır. Ölçeğin güvenirlik hesaplamasında kullanılan Cronbach’s Alpha değerleri .76 ile .95 arasında değişmektedir. Mevcut araştırmada ise Cronbach’s Alpha değerleri .70 ile .92 arasında değişmektedir. Mevcut çalışmada öğretmenlik mesleğine yönelik tutum ile ilgili olarak incelenen boyutlar, sevgi, değer ve uyumdur. Sevgi boyutunun örnek maddeleri "Benim için en ideal meslek öğretmenliktir." , "Bu mesleği bilerek ve isteyerek seçtim." "İleride bu meslekte başarılı olabilmek için çok çalışıyorum." şeklindedir. Değer boyutu örnek maddeleri "Öğretmenlik onurlu bir meslektir." , "Öğretmenlik paylaşımın en yoğun yaşandığı bir meslektir" şeklindedir. Uyum boyutu örnek maddeleri "Sürekli bir sinıfta hapsolmak beni sinirlendirir.", "Öğretmenlik gibi çileli bir mesleğe başlamaktan çekiniyorum." şeklindedir.

\section{Işlem}

Araştırmada elde edilen verilerin analizinde kişisel değerler ve öğretmenlik mesleği tutum ölçeklerinden elde edilen puanlar arasındaki ilişkilerin saptanması için Pearson Çarpım Momentler Korelâsyon Analizi; kişisel değerler ölçeğinden elde edilen puanların öğretmenlik mesleği tutum ölçeğinden elde edilen puanları yordama düzeyinin belirlenmesinde ise Çoklu Doğrusal Regresyon Analizi kullanılmıştır. Analizlerde kişisel değerler envanteri alt boyutlarından disiplin ve sorumluluk, güven ve bağışlama, dürüstlük ve paylaşım, paylaşım ve saygı bağımsız 
değişken olarak alınırken, öğretmenlik mesleğine yönelik tutum ise bağımlı değişken olarak ele alınmıştır.

Veri analizinde eksik ya da hatalı değerler, aykırı değerler ve çoklu bağlantılık incelenmiştir. Eksik verilere ortalama değer atanmıştır. Veri deseninde normal dağılım Q-Q grafiği ve çarpıklık değerlerinin -1 ile +1 arasında kabul edilebilir (-.07 ve -.58) değerlerde olduğu görülmüştür. Çoklu regresyon yapılabilmesi için yordayan değişkenlerle yordanan değişken arasında .30' a yakın korelasyon ve üstünde değerler olduğu görülmektedir. Çoklu bağlantı olup olmadığını görmek için korelasyon VIF ve CI değerlerine bakılmıştır. Yordayıcı değişkenler arasındaki korelasyonların .21 ile .64 arasında değerler aldığı görülmüştür. Verilerin değişkenlere ait puanların regresyon modeline uygunluğu D-W (1.87), çoklu bağlantılılık sorununun olmadığ VIF $(1<\mathrm{VIF}<5)$ değerlerinin saptanmasıyla tespit edilmiştir. Ayrıca koşul indeksi CI değerlerinin 30 'dan yüksek olmadığı görülmektedir. Dolayısıyla verilerin regresyon analizine uygun olduğuna karar verilmiştir.

\section{Bulgular}

Bu bölümde bireysel değerler ve öğretmenlik mesleğine yönelik ortalama ve standart sapma değerleri, ardından korelasyon ve regresyon analizi sonuçları verilmiştir.

\section{Ortalama, standart sapma ve değişkenler arasındaki korelasyonlar}

Tablo I

Bireysel Değerler ve Öğretmenlik Mesleği Tutum Ölçeklerinin ortalamaları ve Standart Sapmaları

\begin{tabular}{|l|l|l|l|}
\hline Değişkenler & $\bar{x}$ & S & n \\
\hline 1-Sevgi & 3.92 & 0.58 & 210 \\
\hline 2-Değer & 4.50 & 0.39 & 210 \\
\hline 3-Uyum & 3.92 & 0.65 & 210 \\
\hline Öğretmenlik Mesleki Tutum [Tüm ölçek] & 4.06 & 0.47 & 210 \\
\hline 4-Disiplin ve Sorumluluk & 4.34 & 0.40 & 210 \\
\hline 5-Güven ve Bağışlama & 3.62 & 0.51 & 210 \\
\hline 6-Dürüstlük ve Paylaşım & 4.35 & 0.40 & 210 \\
\hline 7-Saygı ve Doğruluk & 3.89 & 0.35 & 210 \\
\hline 8-Paylaşım ve Sayg1 & 4.42 & 0.49 & 210 \\
\hline Bireysel Değerler [Tüm ölçek] & 4.11 & 0.32 & 210 \\
\hline
\end{tabular}

Kişisel Değerler envanterinde ortalama puanlar disiplin ve sorumluluk boyutunda $\bar{x}=4.34$, güven ve bağışlama boyutunda $\bar{x}=3.62$, dürüstük ve paylaşım boyutunda $\bar{x}=4.35$ saygı ve doğruluk boyutunda $\bar{x}=3.89$, paylaşım ve saygı boyutunda $\bar{x}=4.42$ bulunmuştur. Kişisel değerler envanteri ortalaması ölçeğin tümü için $\bar{x}=4.11$ bulunmuştur (Tablo 1 ). 
Öğretmenlik mesleği tutum ölçeğinde ortalama puanları sevgi boyutunda $\bar{x}=3.92$, değer boyutunda $\bar{x}=4.50$, uyum boyutunda $\bar{x}=3.92$ bulunmuştur. Öğretmenlik mesleğine yönelik tutum ortalaması ölçeğin tümü için $\bar{x}=4.06$ olarak bulunmuştur (Tablo 1 ).

\section{Tablo 2}

\section{Bireysel Değerler ve Öğretmenlik Mesleğine Yönelik Tutum Arasındaki Korelasyon Matrisi}

\begin{tabular}{|l|l|l|l|l|l|l|l|l|l|}
\hline Değişkenler & $\mathbf{1}$ & $\mathbf{2}$ & $\mathbf{3}$ & $\mathbf{4}$ & $\mathbf{5}$ & $\mathbf{6}$ & $\mathbf{7}$ & $\mathbf{8}$ & $\mathbf{9}$ \\
\hline 1-Disiplin ve sorumluluk & - & & & & & & & & \\
\hline 2-Güven ve bağışlama & $.21^{* *}$ & - & & & & & & & \\
\hline 3-Dürüstlük ve paylaşım & $.73^{* *}$ & $.25^{* *}$ & - & & & & & & \\
\hline 4-Saygı ve doğruluk & $.66^{* *}$ & $.23^{* *}$ & $.63^{* *}$ & - & & & & & \\
\hline 5- Paylaşı ve sayg1 & $.63^{* *}$ & $.25^{* *}$ & $.66^{* *}$ & $.53^{* *}$ & - & & & & \\
\hline 6-Sevgi & $.28^{* *}$ & $.29^{* *}$ & $.29^{* *}$ & $.24^{* *}$ & $.24^{* *}$ & - & & & \\
\hline 7-Değer & $.36^{* *}$ & $.23^{* *}$ & $.38^{* *}$ & $.33^{* *}$ & $.34^{* *}$ & $.41^{* *}$ & - & & \\
\hline 8-Uyum & $.29^{* *}$ & $.31^{* *}$ & $.23^{* *}$ & $.11^{* *}$ & $.21^{* *}$ & $.68^{* *}$ & $.30^{* *}$ & - & \\
\hline 9-Öğretmenlik mesleği tutum & $.34^{* *}$ & $.33^{* *}$ & $.34^{* *}$ & $.29^{* *}$ & $.29^{* *}$ & $.97^{* *}$ & $.56^{* *}$ & $.77^{* *}$ & - \\
\hline
\end{tabular}

${ }^{* *} p<.05$

Öğretmenlik mesleğine yönelik tutum puanları ile disiplin ve sorumluluk $(r=.34, \mathrm{p}<.05)$, güven ve bağışlama $(r=.33, \mathrm{p}<.05)$, dürüstlük ve paylaşım $(r=.34, \mathrm{p}<.05)$, paylaşım ve saygı $(r$ $=.29, \mathrm{p}<.05)$ boyutları arasında istatiksel olarak pozitif yönde anlamlı ilişki olduğu belirlenmiştir (Tablo 2).

\section{Öğretmenlik mesleğine yönelik tutumun yordanması}

\section{Tablo 3}

Öğretmenlik Mesleğine Yönelik Tutumun Yordanmasına llişkin Regresyon Analizi

\begin{tabular}{|l|l|l|l|l|l|}
\hline Değişken & $B$ & $S H_{B}$ & $\beta$ & $t$ & $p$ \\
\hline Sabit & 1.47 & .38 & & 3.78 & .00 \\
\hline Disiplin ve sorumluluk & .17 & .12 & .14 & 1.43 & .15 \\
\hline Güven ve bağışlama & .23 & .06 & .24 & 3.80 & .00 \\
\hline Dürüstlük ve paylaşım & .13 & .11 & .11 & 1.13 & .25 \\
\hline Saygi ve doğruluk & .05 & .12 & .03 & .43 & .66 \\
\hline Paylaşım ve sayg1 & .04 & .08 & .04 & .51 & .60 \\
\hline$R=.44, R^{2}=.19, F=9.98$, & \multicolumn{5}{|l|}{} \\
\hline
\end{tabular}

$p<.05$ 
Kişisel değerlerin bütün alt boyutlarının birlikte öğretmenlik mesleğine yönelik tutum puanını yordama gücü istatiksel olarak anlamlı bulunmuştur $\left.\left(F_{(5-204}\right)=9.98 ; p<.05\right)$. Dört yordayıcı değişken birlikte ele alındığında, kişisel değerler, öğretmenlik mesleğine yönelik tutum puanındaki değişimin \%19'unu açıklayabilmektedir (Tablo3). Bağımsız değişkenler ayrı ayrı incelendiğinde ise, sadece güven ve bağışlama alt boyutunun tek başına öğretmenlik mesleğine yönelik tutumu açıklama gücüne sahip olduğu saptanmıştır $[\beta=.24]$.

\section{Tartışma ve sonuç}

$\mathrm{Bu}$ araştırmada, öğretmen adaylarının bireysel değerleri ve öğretmenlik mesleğine yönelik tutumları arasındaki ilişkiler incelenmiştir. Araştırma sonuçları öğretmen adaylarının bireysel değerlerinin, öğretmenlik mesleğini yönelik tutumlarını yordayan önemli bir değişken olduğunu doğrulamaktadır.

Araştırmada öğretmen adaylarının öğretmenlik mesleğine yönelik tutumları oldukça olumlu bir düzeyde bulunmuştur. Araştırmanın bu bulgularıile paralellikgösteren bulgular bulunmaktadır (Bağçeci, Yıldırım, Kara ve Keskinpalta, 2015; Bektaş ve Nalçacı, 2012; Brown, 1992; Çağlar, 2013; İlğan, Sevinç ve Arı, 2013; Kyriacou, Hultgren ve Stephens, 1999; Özder, Konedralı ve Zeki, 2010; Pehlivan, 2008; Pehlivan, 2010; Temizkan, 2008; Semerci ve semerci, 2004). Ancak baz1 çalışmalarda farklı bulgulara da rastlanmaktadır (Bakırcı, 2015; Eroğlu, 2013; Dağ, 2010). Mevcut çalışmada öğretmenlik mesleğine yönelik tutumun daha çok değer boyutunda yoğunlaştığg, bunu sevgi ve uyum boyutunun izlediği görülmektedir. Bu bağlamda mesleki tutum boyutlarından değer boyutunun daha yüksek algılanması olumlu bir sonuç olarak görülebilir. Çünkü değer boyutunun yüksek düzeyde olması, öğretmen adayları tarafından bu mesleğin ciddi bir meslek olarak algılandığını göstermektedir. Aynı zamanda meslekte işbirliğine önem verilmesi gerektiği, özverili ve sabırlı olmanın öneminin ve vicdani özellikleri kullanmanın mesleki gereklilikler arasında algılandığı söylenebilir. Bunun yanında mesleki tutum özelliklerinden sevgi ve uyumun oldukça olumlu düzeyde algılanması da, bu mesleğin öğretmen adayları tarafından sevilerek yapılacağının bir göstergesi olabilir. Öğretmenlik mesleğine yönelik tutumun oldukça olumlu düzeyde algılanması deneyim ve kişilik ile ilgili etkenlere (Çağlar, 2013), öğretmen adaylarının aldığı eğitime (Bursalığlu, 1994) öğretmen yetiştiren kurumların kültürüne, öğrencilere verilen derslerin niteliğine (Tarman, 2012), pedagojik formasyon derslerinin niteliğine (Bağçeci, Yıldırım, Kara ve Keskinpalta, 2015) bağlıdır. Sosyal, ekonomik ve psikolojik etmenlerde öğretmenliğin meslek olarak seçilmesinde etkilidir (Bursalığlu, 1994). Öğretmenlik mesleğine yönelik tutumun olumlu düzeyde algılanması bu mesleğin halihazırda sevilerek yapılan bir meslek durumunda olduğu söylenebilir. Sonuç olarak, mesleğe değer veren, uyum içinde çalışan öğretmenlerin gerek kurumlarına gerek öğrencilerine mesleki gelişimlerini sağlayarak ve farklı alanlarda kendilerini geliştirerek katkılarının yüksek düzeyde olması beklenebilir.

Araştırmada öğretmen adaylarının, bireysel değerlere sahip olma düzeylerinin yüksek düzeyde olduğu görülmüştür. Öğretmen adaylarının bireysel değerlere sahip olma bakımından en yüksek düzeyin disiplin ve sorumluluk boyutunda olduğu, bu boyutları sırasıyla paylaşım ve 
saygı ile dürüstlük ve paylaşım, saygı ve doğruluk ile güven ve bağışlama boyutlarının izlediği görülmektedir. Bu araştırmanın bulguları, benzer bir çalışmayı yapan Bektaş ve Nalçacı̉nın (2012) bulguları ile paralellik göstermektedir. Çavdar’n (2009) ilköğretim öğretmenlerinin bireysel değerleri ile ilgili yaptı̆̆ı çalışmada da en yüksek düzeyde algılanan boyutun disiplin ve sorumluluk olduğu görülmüştür. Özdemir ve Sezgin’in (2011) çalı̧̧masında öğretmen adaylarının bireysel değerler olarak dürüstlük, saygı ve güven gibi değerleri öncelikli olarak iyi düzeyde algıladıkları görülmüştür. Demir’ in (2015) ilkokul öğretmenlerinin bireysel değerlerden en çok adalet, eşitlik ve dürüstlük değerlerine önem verdikleri görülmüştür. Aktepe ve Yel'in (2009) ilköğretim öğretmenlerine yönelik çalışmasında dürüst olmak, sorumluluk sahibi olmak değerlerini yüksek düzeyde benimsedikleri görülmüştür. Altunay ve Yalçınkayảnın (2011) çalışmasında öğretmen adaylarının geleneksel değerler bağlamında ele alınan adil olmak, ahlaki güven, saygı, sadakat gibi değer alanlarında yüksek düzeyde algıladıkları görülmüştür. Bu çalışmada öğretmen adayları tarafından disiplin ve sorumluluk boyutunun yüksek düzeyde algılanıyor olması olumlu bir sonuç olarak düşünülebilir. Öğretmen adaylarınım mesleğe ciddiyetle yaklaştıkları ve mesleğin gerektirdiği sorumluluklara dair hassasiyetleri olumlu düzeyde algıladıkları söylenebilir. Bireysel değerlerden güven ve bağışlama boyutunun diğer boyutlara göre düşük düzeyde algılanması, öğretmen adaylarının başkalarını affetme ve başkalarına güven ile ilgili sorunlar yaşadıklarının göstergesi olabilir. Bireysel değerlerin olumlu ya da olumsuz düzeyde algılanması farklı nedenlere bağlı olabilmektedir. Bireysel değerler toplumsal yaşama ve kültüre bağlı olarak gelişir (Meglino ve Ravlin, 1998), bireyin entelektüel alanda bir parçası haline gelir (Murphy $v d ., 1997$ ve Russell, 2000'den akt., Uyguç, 2003). Bu bağlamda bireysel değerlerden düşük düzeyde algılanan güven ve bağışlama boyutunun iyileştirilmesi için öğretmen adaylarına yönelik uygulamaya yönelik çalışmalar planlanabilir. Aynı zamanda bu özelliğin düşük çıkma nedenleri üzerinde araştırmalar planlanabilir. Çünkü öğretmen olacak kişilerin mesleğe uygun standartlar taşıması önemlidir (Tekneci, 2010). Bireysel değerlerin olumsuzdan olumluya dönüştürülmesi, bu değerlerin farklı örgüt değişkenleri ile ilişkili olmasından dolayı önemlidir (Yılmaz, 2006; Sezgin, 2006). $\mathrm{Bu}$ ifadelerden hareketle araştırmada bireysel değerlerin genel olarak iyi düzeyde algılanması, öğretmen adayları açısından olumlu bir sonuç olarak görülebilir. Bireysel değerlerin olumlu düzeyde algılanmasının eğitimde olumlu çıktılara neden olacağı söylenebilir.

Araştırmada öğretmen adaylarının bireysel değerlerinin tüm alt boyutları ile öğretmenlik mesleğine yönelik tutumları arasında pozitif yönde ve anlamlı ilişkiler bulunmuştur. Bireysel değerlerden disiplin ve sorumluluk, güven ve bağışlama, dürüstlük ve paylaşım ile öğretmenlik mesleğine yönelik tutum arasındaki ilişkiler birbirine yakın bulunmuştur. İlişkilerin birbirine yakın bulunması, bireysel değerlerin birbirine yakın önemlere sahip olduğunun bir göstergesi olabilir. Bu bulgu Bektaş ve Nalçaci’nın (2012) bulguları ile uyumlu görünmektedir. Demir’in (2015) çalışmasında öğretmenlerin olumlu ve karşılık beklemeden yaptıkları davranışları ile adalet, güven, dürüstlük ve sorumluluk değerleri arasında ilişkiler olduğu bulunmuştur. $\mathrm{Bu}$ bulgulardan hareketle bireysel değerlerdeki olumlu yöndeki bir yükselmenin, öğretmenlik mesleğine yönelik tutumda olumlu yönde bir artış sağlayacağı ya da tersi söylenebilir. Bireysel değerler bireylerin davranışlarında nelerin öncelikli yapılacağını belirlemektedir (Cartwright, 
2007). Bunun yanında bireysel değerlerin, tutumları ve davranışları etkilediğine dair kanıtlar bulunmaktadır (Homer ve Kahle 1988; Papagiannakis and Lioukas, 2012). Okulların başarı sağlamasında öğretmenlerin yapması gereken görevleri dışında, gönüllü yaptıkları çalışmaların ve kuruma her alanda yaptıkları katkıların etkili olduğu görülmüştür (Somech ve Ron, 2007). Öğretmenlerin gönüllü çalışmalarında bireylerin değerleri ve tutumlarının önemli olduğu söylenebilir. Bu bakımdan örgütsel davranış içinde bireyleri motive eden değerlerin anlaşılması önemlidir (Robbins, 1992 ve Tracy, 1989'dan akt., Sağnak, 2004). Çünkü bireysel değerler bir faaliyeti sürdürmenin temellerini sağlamaktadır. Aynı zamanda değerler bireylerin olumlu ya da olumsuz davranışlarını açıklamaya çalışır (Feather, 2002'den akt. Demir, 2015). Tutumlar olumlu ya da olumsuz bazı davranışların nedeni olabilir (Tavşancıl, 2004). Bireysel değerler ile mesleğe yönelik tutumun anlamlı ilişkilerin olması bu bağlamda önemli bir sonuç olarak görülebilir. Araştırmada, öğretmen adaylarının bireysel değerlerinin yükselmesi ile birlikte, öğretmenlik mesleğine yönelik tutumlarında bir artışın gerçekleştiği görülmektedir. Bu ifadelere göre öğretmen adaylarının öğretmen adaylarının bireysel değerlerinin öğretmenlik mesleğine yönelik tutumda önemli bir değişken olduğu söylenebilir.

Araştırmada öğretmen adaylarının bireysel değerlerinin mesleğe yönelik tutumlarını yordama düzeyleri incelenmiştir. Bireysel değerler alt boyutlarından güven ve bağışlama, öğretmenlik mesleğine yönelik tutumun anlamlı bir yordayıcısı olarak bulunmuştur. Farklı bazı çalışmalar öğretmenlik mesleğine yönelik tutumu yordayan değişkenlerin farklı olabildiği görülmüştür. Bektaş ve Nalçacı'nın (2012) çalışmasında disiplin ve sorumluluk ile paylaşım ve sevgi alt boyutlarının ayrı ayrı öğretmenlik mesleğine yönelik tutumu yordadığı görülmüştür. Bu çalışma ile Bektaş ve Nalçacı'nın (2012) bulguları arasındaki farklılık çalışma gruplarının özelliklerinden kaynaklanıyor olabilir. Dolayısıyla, sonuçları daha iyi anlamlandırmak için, bu çalışmaya benzer çalışmalar farklı gruplarda yeniden uygulanabilir. Bu sonuçlara göre güven ve bağışlama değerine yönelik algıları yüksek düzeyde olan öğretmen adaylarının öğretmenlik mesleğine yönelik tutumlarının olumlu düzeyde olacağı söylenebilir. Örgütlerin başarıları değerleri paylaşma, güven ile yakından ilişkilidir (Cafoğlu, 1999). Okullarda etkileşimi sağlama ve paydaşlar arasında güven duygusuna sahip olma önemlidir (Hoy ve Miskel, 2010). Güven sorunu yaşanan kurumların ilerlemesi beklenmez (Hurley ve Siebers, 2007). Güvenin olduğu ortamlarda bağlılık ve dayanışma artar (Neves ve Caetano, 2006). Güven araç bir değer olarak görülüp, amaç değere ulaşmada araç olarak görülebilir (Çavdar, 2009). Bağışlama değeri yüksek olan öğretmenler öğrencilere daha ilgilidir ve onlar ile daha yakın ilişkiler kurmaktadırlar (Aydın, 1995). Güven ve bağışlama değerinin yüksek düzeyde olması mesleğe yönelik tutumunun daha olumlu olmasına neden olabilir. Öğretmenlik mesleğini yapmak isteyen kişilerde iletişimi kolaylaştıracak, güven ve bağışlama gibi değerlerin daha ön planda olması gerektiği söylenebilir. Bu bağlamda güven ve bağışlama değerine sahip öğretmenlerin, öğrencilere anlayışlı davranmaları ve yardımcı olmaları beklenir. Bu ifadelerden hareketle, öğretmen adaylarının bireysel değerlerinin yeterli düzeyde olmasının, mesleğe yönelik tutuma olumlu yönde katkı sağlaması beklenebilir.

Araştırmanın önemli sonuçları şöyle özetlenebilir: (i) Öğretmen adaylarının öğretmenlik mesleğine yönelik tutumları oldukça olumlu bir düzeyde bulunmuştur, (ii) Öğretmen adaylarının, 
bireysel değerlere sahip olma düzeylerinin yüksek düzeyde olduğu görülmüştür, (iii) Öğretmen adaylarının bireysel değerlerinin tüm alt boyutları ile öğretmenlik mesleğine yönelik tutumları arasında pozitif yönde ve anlamlı ilişkiler bulunmuştur (iv) Bireysel değerler alt boyutlarından güven ve bağışlama, öğretmenlik mesleğine yönelik tutumun anlamlı bir yordayıcısı olarak bulunmuştur.

Araştırmadaki sonuçlara göre bireysel değerlerin öğretmenlik mesleğine yönelik tutumu açıklamasından dolayı önemli bir değiş̧ken olduğu belirtilebilir. Bu bakımdan, öğretmen adaylarına yönelik bireysel değerleri geliştirmeye ve değerlerle ilgili farkındalı̆̆ı artırmaya yönelik çalışmalar ve öğretmen yetiştirme programlarında bireysel değerlerin geliştirilmesine yönelik etkinlikler düzenlenebilir. Bu bağlamda farklı bireysel değerlerin doğrudan ya da dolaylı şekilde geliştirilmesine yönelik öğretmen adayları ile sosyal sorumluluk temelli projeler hazırlanabilir. Öğretmen adaylarının ahlaki muhakeme, değer açıklama ve değer analizi yaklaşımları ile bireysel değerleri üzerinde düşünmeleri ve farkındalık oluşturmak için bilişsel süreçlerin kullanıldığ faaliyetler planlanabilir (Akbaş, 2008).

Araştırma sonuçlarına dayanarak, bireysel değerler ile mesleğe yönelik tutumu belirleyen çalışmalara ihtiyaç olduğu söylenebilir. Çünkü değer ve tutum kavramını ayrı ayrı inceleyen çalışmalar bulunmakla birlikte, aralarındaki ilişkiyi araştıran çalışmaların sayısı sınırlı düzeydedir. Çalışma sayısı artarsa iki kavram arasındaki ilişkiye dair daha net sonuçlar elde edilmesi mümkün olabilir. Bu araştırmadan elde edilen sonuçların farklı nitel çalışmalarla desteklenmesi ve ya derinlemesine çalışmalar yapılması faydalı olabilir. Başka çalışmalarda ise öğretmenlik mesleğine yönelik tutumu etkileyen faktörler nedensel ilişkileri ortaya çıkarmaya yönelik olarak yapılabilir. Ayrıca farklı teorik değer sınıflamaları bağlamında araştırma tekrar edilebilir. 


\section{Kaynaklar}

Akbaş, O. (2008). Değerler eğitimi akımlarına genel bir bakıș. Değerler Eğitimi Dergisi, 6(16), 9-27.

Aktay, A. ve Ekşi, H. (2009). Yönetici ve öğretmenlerin değer tercihleri ile örgütsel vatandaşlık davranışları arasındaki ilişki. İş Ahlakı Dergisi, 2 (1), 19-65.

Aktepe, V. ve Yel, S. (2009). İlköğretim öğretmenlerinin değer yargılarının betimlenmesi: Kırşehir ili örneği. Türk Eğitim Bilimleri Dergisi, 7(3), 607-622.

Altunay, E. \& Yalçınkaya, M. (2011). Öğretmen adaylarının bilgi toplumunda değerlere ilişkin görüşlerinin bazı değişkenler açısından incelenmesi. Kuram ve Uygulamada Eğitim Yönetimi, 17 (1), 5-28.

Asan H. T., Ekşi, F., Doğan, A. ve Ekşi, H. (2008). Bireysel Değerler Envanteri’nin dilsel eşdeğerlik, geçerlik ve güvenirlik çalışması. Marmara Üniversitesi Atatürk Eğitim Fakültesi Eğitim Bilimleri Dergisi, 27, $15-38$.

Aydın, O. (1995). Sınıf öğretmeni adaylarının psikolojik ihtiyaçları ile öğretmenlik tutumları arasındaki ilişki. Marmara Üniversitesi Atatürk Eğitim Fakültesi Eğitim Bilimleri Dergisi, 7, 23-34.

Bachkirova, T. (2005). Teacher stress and personal values: An exploratory study. School Psychology International, 26(3), 340-352. doi:10.1177/0143034305055978

Bağçeci, B., Yıldırım, İ., Kara, K., ve Keskinpalta, D. (2015). A comparative study on the attitudes of students from education faculties and science faculties towards being a teacher. Journal of Education Faculty, 17(1), 307-324.

Bakırc1, Y. (2015). Beden eğitimi öğretmen adaylarının öğretmenlik mesleğine yönelik tutumlarının incelenmesi. (Yayınlanmamış Yüksek Lisans Tezi). Sosyal Bilimler Enstitüsü, Aksaray Üniversitesi. https://tez. yok.gov.tr/UlusalTezMerkezi adresinden indirilmiştir.

Bektaş, F. ve Nalçacı, A. (2012). Bireysel değerler ve öğretmenlik mesleğine yönelik tutum arasındaki ilişki. Kuram ve uygulamada Eğitim Bilimleri (Ek özel sayı), 12 (2), 1239-1248.

Bhattacharyya, A. (2014). Personal values and attitudes towards societal and environmental accountability: A study of MBA students. Environmental Education Research, 1-21. doi:10.1080/13504622.2014.9 66658

Bozdoğan, A. E., Aydın, D., ve Yıldırım, K. (2007). Öğretmen adaylarının öğretmenlik mesleğine ilişkin tutumları. Ahi Evran Üniversitesi Kırşehir Eğitim Fakültesi Dergisi, 8(2).

Brown, M. M. (1992). Caribbean first-year teachers"e reasons for choosing teaching as a career. Journal of Education for Teaching, 18(2), 185-195.

Bursalıoğlu, O. (1994). Okul yönetiminde yeni yapı ve davranış. Ankara: Pegem A Yayıncılık.

Cafoğlu, Z. (1999). Eğitimde yeni değerlere doğru. Bilig Türk Dünyası Sosyal Bilimler Dergisi Dergisi,9, 147159.

Carr, D. (2006). Professional and personal values and virtues in education and teaching, Oxford Review of Education, 32(2), 171-183, doi: 10.1080/03054980600645354

Cartwright, T. (2007). Setting priorities : Personal values, organizational results. Greensboro, NC, USA.

Chong, S., ve Low, E. (2009). Why I want to teach and how I feel about teaching formation of teacher identity from pre-service to the beginning teacher phase. Educational Research for Policy and Practice, 8(1), 59-72. doi:10.1007/s10671-008-9056-Z

Collinson, V. (2012). Sources of teachers' values and attitudes. Teacher development, 16(3), 321-344. doi:10. $1080 / 13664530.2012 .688675$

Çağlar, Ç. (2013). Eğitim fakültesi öğrencilerinin yabancılaşma düzeyleri ile öğretmenlik mesleğine yönelik tutumları arasındaki ilişki. Kuram ve Uygulamada Eğitim Bilimleri, 13(3), 1497. 
Çavdar, M. (2009). İlköğretim öğretmenlerinin bireysel değerlerinin çok boyutlu incelenmesi. (Yayınlanmamış Yüksek Lisans Tezi). Sosyal Bilimler Enstitüsü, Yeditepe Üniversitesi. https://tez.yok.gov.tr/ UlusalTezMerkezi adresinden indirilmiştir.

Çeliköz, N. ve Çetin, F. (2004). Anadolu öğretmen lisesi öğrencilerinin öğretmenlik mesleğine yönelik tutumlarını etkileyen etmenler. Milli Eğitim Dergisi, 162, 136-145.

Çetin, Ş. (2006). Öğretmenlik mesleği tutum ölçeğinin geliştirilmesi (Geçerlik ve güvenirlik çalışması). Gazi üniversitesi endüstriyel sanatlar eğitim fakültesi dergisi, 18, 28-37.

Dağ, E. (2010). Sınıf öğretmeni adaylarının öğretmenlik mesleğine yönelik tutumları ile öğretmenlik mesleğini tercih etmelerinde etkili olan faktörler arasındaki ilişki (İzmir ili örneği). (Yayınlanmamış Yüksek Lisans Tezi). Ege Üniversitesi Sosyal Bilimler Enstitüsü, İzmir. https://tez.yok.gov.tr/ UlusalTezMerkezi adresinden indirilmiştir.

Demir, T.G. (2015). Öğretmenlerin sergiledikleri rol fazlası davranışlar ve bireysel değerler ile ilişkisi. (Yayınlanmamış Yüksek Lisans Tezi). Eğitim Bilimleri Enstitüsü, Ankara Üniversitesi. https://tez. yok.gov.tr/UlusalTezMerkezi adresinden indirilmiştir.

Ekşi, H. (2003). Temel insani değerlerin kazandırılmasında bir yaklaşım: Karakter eğitimi programları. Değerler Eğitimi Dergisi, 1 (1), 79-96.

Eroğlu, C. (2013). Beden eğitimi öğretmen adaylarının özyeterlikleri ve öğretmenlik mesleğine yönelik tutumları. (Yayınlanmamış Yüksek Lisans Tezi). Sosyal Bilimleri Enstitüsü, Aksaray Üniversitesi. https://tez.yok.gov.tr/UlusalTezMerkezi adresinden indirilmiştir.

Fisher, Y. (2013). Exploration of values: Israeli teachers' professional ethics. Social Psychology of Education, 16(2), 297-315. doi:10.1007/s11218-013-9211-0

Gibb, K. (2010). Personal values. Relational Child and Youth Care Practice, 23(3), 40.

Güngör, E. (1993). Değerler psikolojisi. Amsterdam: Hollanda Türk Akademisyenler Birliği Vakfı Yayınları.

Homer, P. M., ve Kahle, L. R. (1988). A structural equation test of the value-attitude-behavior hierarchy. Journal of Personality and Social Psychology, 54(4), 638-646.

Hoy, W.K. ve Miskel, C.G. (2010). Educational Administration (çev. editör: Selahattin Turan), Ankara: Nobel Yayın Dağıtım.

Hurley, P. ve Siebers, J. (2007). Companies without trust will fail to thrive, Strategic Comminication Management,11(4),7.

İlğan, A., Sevinç, Ö. S. ve Arı, E. (2013). Pedagojik formasyon programı öğretmen adaylarının mesleki tutum ve çağdaş öğretmen algıları. Ondokuz Mayıs Üniversitesi Eğitim Fakültesi Dergisi, 32(2), 175-195.

Kaşkaya, A., Ünlü, İ., Akar, M. ve Sağırlı, M.Ö. (2011). Okul ve öğretmen içerikli sinema filmlerinin öğretmen adaylarının mesleki tutumlarına ve öz yeterlik algılarına etkisi. Kuram ve Uygulamada Eğitim Bilimleri Dergisi, 11(4), 1765-1783.

Katılmış, A., Ekşi, H., ve Öztürk, C. (2011). Sosyal bilgiler ders kazanımlarıyla bütünleştirilmiş karakter eğitimi programının etkililiği. Kuram ve Uygulamada Eğitim Bilimleri, 11(2), 839-859.

Kılıç, M. (2011). Değerler filozofisi ve hukuksal değerler. Eğitime Bakış, 7(19), 51-54.

Kılcan, B., Keçe, M., Çepni, O., ve Kılınç, A. Ç. (2014). Prospective teachers' reasons for choosing teaching as a profession. Kastamonu Eğitim Dergisi, 22(1), 69-80.

Kluckhohn, C. (1951). Values and value-orientations in the theory of action: An exploration in definition and classification. In T. Parsons \& E. Shils (Eds.), Toward a general theory of action (pp. 388-433). Cambridge, MA: Harvard University Press.

Kyriacou, C., Hultgren, A. ve Stephens, P. (1999). Student teacherss"e motivation to become a secondary school teacher in England and Norway. Teacher Development, 3(3), 373-381 
Meglino, B. M., ve Ravlin, E. C. (1998). Individual values in organizations: Concepts, controversie and research. Journal of Management, 24(3), 351-389. doi:10.1177/014920639802400304

Neves, P., ve Caetano, A. (2006). Social exchange processes in organizational change: The roles of trust and control. Journal of Change Management, 6(4), 351-364.

Özdemir, S. ve Sezgin, F. (2011). Öğretmen adaylarının bireysel ve örgütsel değerler ile öğrencilerde görmek istedikleri değerlere ilişkin önem sırası algıları. Uşak Üniversitesi Sosyal Bilimler Dergisi, 2011(8).

Özder, H., Konedralı, G. ve Zeki, C.P. (2010). Öğretmen adaylarının öğretmenlik mesleğine yönelik tutumlarının çeşitli değişkenler açısından incelenmesi. Kuram ve uygulamada eğitim yönetimi, 16 (2).

Özensel, E. (2003). Sosyolojik bir olgu olarak değer. Değerler Eğitimi Dergisi, 3, 217-239.

Papagiannakis, G., ve Lioukas, S. (2012). Values, attitudes and perceptions of managers as predictors of corporate environmental responsiveness. Journal of Environmental Management, 100, 41-51. doi:10.1016/j.jenvman.2012.01.023

Pehlivan, K. B. (2008). Sınıf öğretmeni adaylarının sosyo-kültürel özellikleri ve öğretmenlik mesleğine yönelik tutumları üzerine bir çalışma. Mersin Üniversitesi Eğitim Fakültesi Dergisi, 4(2).

Pehlivan, K. (2010). Öğretmen adaylarının öğrenme stilleri ve öğretmenlik mesleğine yönelik tutumları üzerine bir çalışma. İlköğretim Online, 9(2), 749-763.

Rokeach, M. (1973). The Nature of Human Values, NewYork: The Free Press.

Roy, A. (2003). Factor analysis and initial validation of the personal values inventory. Unpublished doctorate dissertation, Tennessee State University, USA.

Sağlam, A. Ç. (2008). Müzik öğretmenliği bölümü öğrencilerinin öğretmenlik mesleğine yönelik tutumları. Yüzüncü Yll Üniversitesi Eğitim Fakültesi Dergisi, 5(1), 59-69.

Sağnak, M. (2004). Kişi-örgüt değer uyumunu ölçme çalışmaları ve kullanılan yöntemlerin karşılaştırılması. Değerler Ĕ̈itimi Dergisi, 2(5), 101-124.

Schwartz, S. H. (2012). An Overview of the Schwartz Theory of Basic Values. Online Readings in Psychology and Culture, 2(1). http://dx.doi.org/10.9707/2307-0919.1116

Schwartz, S. H., Melech, G., Lehmann, A., Burgess, S. A. M., ve Harris, M. (2001). Extending the crosscultural validity of the theory of basic human values with a different method of measurement. Journal of Cross Cultural Psychology, 32, 519- 542.

Semerci, N. ve Semerci, Ç. (2004). Türkiye’de öğretmenlik tutumları. Fırat Üniversitesi Sosyal Bilimler Dergisi, 14(1), 137-146.

Sezgin, F. (2006). İlköğretim okulu öğretmenlerinin bireysel ve örgütsel değerlerinin uyumu. (Yayınlanmamış Doktora Tezi). Gazi Üniversitesi, Ankara.

https://tez.yok.gov.tr/UlusalTezMerkezi adresinden indirilmiştir.

Somech, A. ve Ron, I. (2007). Promoting organizational citizenship behavior in schools: The impact of individual and organizational characteristics. Educational Administration Quarterly, 43(1), 38-66. doi:10.1177/0013161X06291254

Spranger, E.(1928). Types of men. New York: Stechert-Hafner.

Tarman, B. (2012). Perspective teachers' beliefs and perceptions about teaching as a profession. Educational Sciences: Theory \& Practice, 12(3), 1964-1973.

Tavşancıl, E. (2014). Tutumların ölçülmesi ve SPSS ile veri analizi. Ankara: Nobel Yayınları

Tekneci, E. (2010). Zihin engelliler öğretmenliği 1. ve 4. sinı öğrencilerinin öğretmenlik mesleğine yönelik tutumları ile kaygı düzeylerinin karşılaştırılması. (Yayınlanmamış Yüksek Lisans Tezi). Marmara Üniversitesi, İstanbul. https://tez.yok.gov.tr/UlusalTezMerkezi adresinden indirilmiştir. 
Marmara Üniversitesi Atatürk Eğitim Fakültesi Eğitim Bilimleri Dergisi / Journal of Educational Sciences

YIl: Haziran 2016 • Cilt-Sayı $44 \cdot$ ISSN: I300-8889 • ss. I25-I4I

Temizkan, M. (2008). Türkçe öğretmeni adaylarının öğretmenlik mesleğine yönelik tutumları üzerine bir araştırma. Türk Eğitim Bilimleri Dergisi, 6(3).

Usal, A. ve Aslan, Z. (2006). Davranış bilimleri. (5.baskı). İzmir: Meta Basım.

Uyguç, N. (2003). Cinsiyet, bireysel değerler ve meslek seçimi. D.E.Ü. İktisadi ve İdari Bilimler Fakültesi Dergisi, 18 (1).

Uzun, E.B. (2014). Sınıf öğretmenlerinin sahip olduğu değerler ile akademik iyimserlik düzeyleri arasındaki ilişki. (Yayınlanmamış Yüksek Lisans Tezi). Eğitim Bilimleri Enstitüsü, Gazi Üniversitesi, Ankara. https://tez.yok.gov.tr/UlusalTezMerkezi adresinden edinilmiştir

Üstüner, M., Demirtaş, H. ve Cömert, M. (2009). The attitudes of prospective teachers towards the profession of teaching. The case of İnönü University, Faculty of Education. Education and Science, 34(151), 140-155.

Yllmaz, K. (2006). İlköğretim okulu yönetici ve öğretmenlerine göre kamu ilköğretim okullarında bireysel ve örgütsel değerler ve okul yöneticilerinin okulların bu değerlere göre yönetme durumları. (Yayınlanmamış Doktora Lisans Tezi). Eğitim Bilimleri Enstitüsü, Ankara Üniversitesi, Ankara. https://tez.yok.gov.tr/UlusalTezMerkezi adresinden indirilmiştir. 
